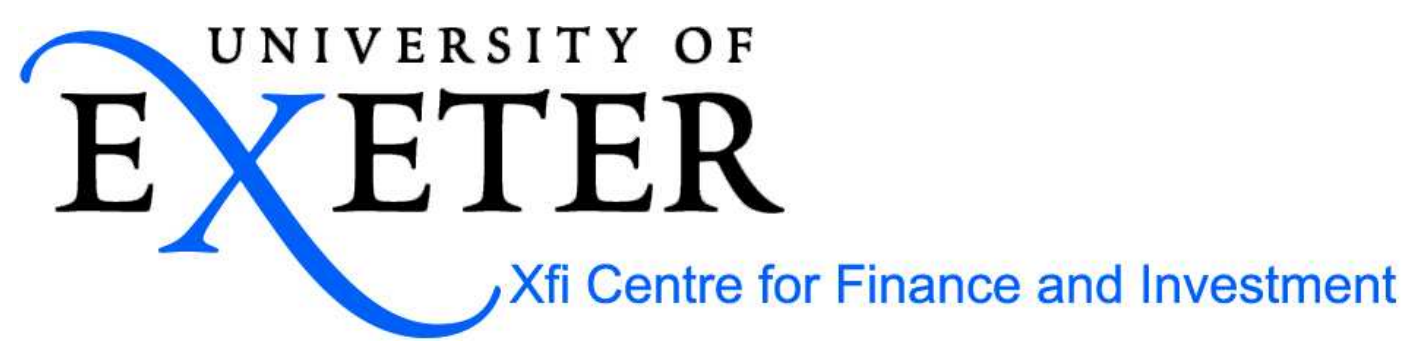

\title{
Equity block transfers in transition economies: Evidence from Poland
}

\author{
Grzegorz Trojanowski* \\ Xfi Centre for Finance and Investment, University of Exeter
}

This version: December 2005

Paper Number: 06/06

\begin{abstract}
:
This paper investigates the valuation effects of share block transfers and employs agency theory to explain the determinants of equity block premia. A sample of transactions from Poland is used to measure the benefits and costs of ownership concentration. Block premia are found to be substantially lower than in well-developed markets, in spite of the weaker minority shareholders' protection in transitional economies. Shareholders expect to benefit from intensified monitoring and from corporate restructuring resulting from block acquisitions (even if such acquisitions are not followed by a subsequent takeover). Still, shareholders are wary of the expropriation stemming from the extraction of private benefits of control by block holders. The opportunities to extract such benefits are found to depend not only on the size of the block holder's stake, but also on the relative power of other investors. Finally, the results document a positive role of the State as an investor in listed companies.
\end{abstract}

JEL classification: G30, G32, G34.

Keywords: Agency problems, corporate governance, ownership structure, block trades, transition economies.

\footnotetext{
* Address for correspondence: Xfi Centre for Finance and Investment, University of Exeter, Xfi Building, Rennes Drive, Exeter EX4 4ST, UK. Tel.: +44 1392 263441; fax: +44 1392 262525; e-mail: G.Trojanowski@ex.ac.uk. I would like to thank Steffan Berridge, Jana Fidrmuc, Ulrich Hege, Martyna Janowicz, Marco Pagano, Dorota Piaskowska, Luc Renneboog, Frans de Roon, other members of my Ph.D. committee, the anonymous referee, and the participants of the CEPR Transition Economics Workshop in Portoroz (2001), the $16^{\text {th }}$ European Economic
} 
Association Annual Congress in Lausanne (2001), the workshop 'Corporate Governance in Transition Economies' in Moscow (2002), the $30^{\text {th }}$ Annual Meeting of the European Finance Association in Glasgow (2003), and the seminars in Tilburg and Paris for helpful comments on earlier drafts of this paper. All remaining errors are mine. Earlier version of this paper appeared as CEPR Discussion Paper no. 3280. 


\title{
Equity block transfers in transition economies: Evidence from Poland
}

\begin{abstract}
:
This paper investigates the valuation effects of share block transfers and employs agency theory to explain the determinants of equity block premia. A sample of transactions from Poland is used to measure the benefits and costs of ownership concentration. Block premia are found to be substantially lower than in well-developed markets, in spite of the weaker minority shareholders' protection in transitional economies. Shareholders expect to benefit from intensified monitoring and from corporate restructuring resulting from block acquisitions (even if such acquisitions are not followed by a subsequent takeover). Still, shareholders are wary of the expropriation stemming from the extraction of private benefits of control by block holders. The opportunities to extract such benefits are found to depend not only on the size of the block holder's stake, but also on the relative power of other investors. Finally, the results document a positive role of the State as an investor in listed companies.
\end{abstract}

JEL classification: G30, G32, G34.

Keywords: Agency problems, corporate governance, ownership structure, block trades, transition economies. 


\section{Introduction}

The presence of agency conflicts between shareholders and managers who control corporate resources in modern companies has led to the emergence of governance mechanisms assuring that financiers' funds are not expropriated or wasted on unattractive projects (Shleifer and Vishny, 1997). In a vast majority of European countries, ownership concentration is one of the most important internal mechanisms of corporate governance (Becht and Röell, 1999). Minority shareholders' protection in these countries is weaker than in Anglo-American ones (La Porta et al., 1998), and therefore, only large blocks, carrying significant control power, provide appropriate guarantees for investors.

This paper takes an agency perspective to explain both costs and benefits of ownership concentration. Large block holdings help to curb agency problems between shareholders, who finance companies, and managers, who control corporate resources on a day-to-day basis (Admati et al., 1994; Maug, 1998; Kahn and Winton, 1994). Yet, delegation of monitoring to large shareholders may be a source of other agency problems that emerge for various stakeholders of a firm (Burkart et al., 2000). As neither the costs, nor the benefits of ownership concentration are directly observable, I analyze agency problems of ownership concentration by studying block transactions. In particular, I examine the announcement effects of block transactions and the determinants of block premia (as in Banerjee et al., 1997 and Bethel et al., 1998).

There exists vast empirical literature analyzing block holdings and block transactions within the agency framework. ${ }^{1}$ However, the focus has been mainly on developed economies, in which minority investors are relatively well-protected. This paper is one of the first in-depth studies of block transfers in a transition economy. ${ }^{2}$ I analyze a sample of block transactions from

\footnotetext{
${ }^{1}$ Recent contributions include Holderness and Sheehan (1988), Barclay and Holderness (1989, 1991, 1992), Zingales (1994, 1995), Sudarsanam (1996), Keim and Madhavan (1996), Banerjee et al. (1997), Bethel et al. (1998), Dyck and Zingales (2004). Their findings are summarized in the next section.

${ }^{2}$ Gregoric and Vespro (2003) analyze a small sample of block transactions in Slovenian listed firms. Atanasov (2001) investigates block transfers and private benefits of control in a larger sample of Bulgarian companies, but his
} 
Poland for the following reasons. First, analyzing data from a young market enables me to detect certain phenomena that are specific to corporate governance in emerging markets, such as insufficient protection of minority shareholders' rights, lack of minority shareholders' expertise, and the special role of the State Treasury. Second, a large number of block transactions and little 'legacy' ownership structures in Polish companies make them a particularly interesting object of analysis. Last but not least, employing a so far unexploited data set allows me to avoid the datasnooping bias.

The paper documents the remarkably low level of block premia in Poland which occurs in spite of the inferior governance standards in transition economies. One plausible reason is the presence of liquidity costs that influence the level of block premia. Shareholders expect to benefit from monitoring and corporate restructuring stimulated by block acquirers. The results indicate that favorable market reaction to a block transaction cannot be explained by the expectation of a future takeover and can be attributed to the actual improvement in firm's operating performance that follows the block transfer. Still, shareholders are wary of the expropriation stemming from the extraction of private benefits of control by large block holders. The opportunities to extract such benefits are found to depend not only on the size of the block holder's stake, but also on the relative power of other investors. The additional result of the analysis is that privatizations are perceived less favorably by the market than other types of block transfers.

The remainder of the paper is organized as follows. Section 2 discusses the role of ownership concentration from an agency theory perspective and surveys the related empirical literature. Section 3 develops and motivates research hypotheses concerning the valuation effects of block transactions and determinants of block premia. In the subsequent part, the methodology is explained. Section 5 provides details on data collection procedure and description of variables. Section 6 outlines the results pertaining to the valuation effects of block transactions, while the next section summarizes the evidence concerning the determinants of block premia. Section 8

sample is restricted to privatization deals only. Finally, the cross-country study by Dyck and Zingales (2004) only includes a tiny set of observations from Czech Republic and Poland. 
verifies the anticipated takeover explanation for the results and discusses additional analyses and robustness checks. The last section concludes.

\section{Prior research}

\subsection{Theoretical background}

The presence of a large shareholder procures benefits, but also comes at a cost. Shleifer and Vishny (1986) and Kyle and Vila (1991) suggest that the presence of a block holder in a company's ownership structure makes value-increasing takeovers possible, and thus helps to overcome free-rider problems pointed out by Grossman and Hart (1980). Moreover, Admati et al. (1994), Maug (1998), Kahn and Winton (1998) show that in the presence of block holders, costly monitoring takes place despite free-riding behavior of dispersed shareholders. The costs of concentrated ownership may be substantial, however. First, control by a large shareholder results in reduced risk sharing (Demsetz and Lehn, 1985; Admati et al., 1994). Second, equity concentration reduces market liquidity (Coffee, 1991; Bolton and Thadden, 1998). ${ }^{3}$ Third, monitoring by an investor holding an equity stake can lead to excessive risk taking in managerial decisions, especially in highly leveraged companies (Jensen and Meckling, 1976; Coffee, 1991). Fourth, Burkart et al. (1997) and Pagano and Röell (1998) point out that even when tight control by shareholders is ex post efficient, ex ante it constitutes an expropriation threat that reduces managerial incentives to exert effort and undertake value-maximizing strategies (the so-called 'over-monitoring' effect).

Grossman and Hart (1988) stress that a significant stake in a company brings about benefits of control, which can be divided into two classes: private benefits and security benefits. The latter class includes benefits of ownership concentration that are shared and enjoyed by all shareholders (e.g. positive effects of monitoring). Control rights can also provide (large) investors with private benefits of control, when these investors have access to private information, are able

\footnotetext{
${ }^{3}$ Coffee (1991) argues that only an illiquid market makes institutional investors intervene rather than sell their stakes. Bolton and Thadden (1998) illustrate that the costs of having a large shareholder may outweigh the benefits, even if the control by block holders always has a positive externality on other shareholders.
} 
to freeze-out minority shareholders at a price below the value of their shares, and - in extreme cases - can divert resources from security holders to entities controlled by a block holder (Zwiebel, 1995; Pagano and Röell, 1998; Johnson et al., 2000). Private benefits of control do not necessarily lead to firm value destruction, but in many cases they may result in inefficiencies. Thus, although block holdings can be a mechanism that mitigates agency costs resulting from excessive managerial discretion, these block holdings may bring in another type of agency costs. A large investor may attempt to expropriate small shareholders' rights. Moreover, according to Zwiebel (1995), private benefits of control can be extracted even if a company has multiple large shareholders. He claims that these benefits are divisible, and parties can enjoy them accordingly to their strategic importance measured by Shapley values. Above some threshold, a large block will not be challenged for control. This encourages extraction of private benefits of control at the expense of dispersed small shareholders, and therefore can induce agency problems between various groups of shareholders.

Sale-of-control transactions (as opposed to tender offers) are not plagued by free-rider and pressure-to-tender problems on the seller's side. Still, efficiency problems do arise because such transactions may well have externality effects on minority shareholders (Bebchuk, 1994). As a result of such externalities, inefficient transfers of control may occur, and efficient transfers of control may be frustrated. ${ }^{4}$ In a similar vein, Burkart et al. (2000) compare various methods of transferring corporate control and conclude that an increase of the block size effectuated via a block transaction, rather than via a tender offer, may signal an inefficient transfer of control. The reason is that transferring control through a block trade preserves the low concentration of the ownership and the corresponding high extraction of private benefits (Bennedsen and Wolfenzon, 2000).

\footnotetext{
${ }^{4}$ Inefficient transfers of control occur when the buyer acquires control to extract private benefits of control rather than to monitor and/or improve company's performance. The value of the firm after such a transaction might decrease, but the acquirer is compensated with excessive private benefits of control for the loss on the value of his shares.
} 


\subsection{Empirical evidence on valuation effects of block trades}

Earlier studies find that block transfers are accompanied by positive abnormal stock performance, and thus, on average, value creating (Holderness and Sheehan, 1988; Sudarsanam, 1996). This effect is documented to be present regardless of the price paid in the transaction (Barclay and Holderness, 1989). The threat of consuming corporate wealth is argued to be absent, since in most companies with a majority shareholder his stake substantially exceeds 50\%-threshold (Holderness and Sheehan, 1988). Barclay and Holderness (1991) claim that changes in control improve corporate governance and increase management turnover as well as the intensity of reorganization activities, rather than bring about additional agency problems. Therefore, block transactions in which the purchaser gains control receive a much more favorable market reaction than those where this is not the case. The market appraisal of block transfers is more favorable if such block transfers are accompanied by a tender offer on all outstanding shares (Holderness and Sheehan, 1988). Furthermore, the market also reacts more positively to block transactions for those firms that experience a full acquisition in a post-trade period (Barclay and Holderness, 1992). Still, even when no subsequent takeover occurs, Sudarsanam (1996) documents that the benefits of ownership concentration outweigh the costs: the announcement effect of a block transaction increases with the size of the stake accumulated by the block acquirer.

More recent studies weaken these unconditionally positive conjectures concerning large shareholders. Banerjee et al. (1997) find no abnormal performance that would accompany block transactions in France. However, they argue that the buyer's identity matters for the valuation effect of the block transfer. Specifically, block acquisitions by holding companies may result in value destruction. Bethel et al. (1998) show that in the US the block purchases by either financial or strategic investors cause no significant market reaction, while acquisitions of blocks by activist shareholders are accompanied by significant positive abnormal performance. Such shareholders usually acquire stakes in poorly performing companies, and subsequently pursue restructuring measures leading to considerable improvement of targets' performance (Nesbitt, 1994). 


\subsection{Private benefits of control and determinants of block premia - empirical evidence}

The empirical literature provides support for the existence of private benefits of control, which are found to increase with the size of the stake held by a given block holder (Barclay and Holderness, 1989, 1992; Zingales, 1994, 1995). The benefits depend on ownership structure and vary significantly among countries, possibly due to the differing corporate governance and legal regimes (Nenova, 2003). Estimates of the value of control range from $-4 \%$ (in Japan) to $65 \%$ (in Brazil) of the value of the company's equity (Dyck and Zingales, 2004). Moreover, control rents are affected by firm-specific characteristics, such as industry, company size, leverage, risk, prior performance, corporate charter provisions, and particular characteristics of voting rights (Nicodano and Sembenelli, 2000; Nenova, 2003; Dyck and Zingales, 2004).

Various studies differ with respect to the methodology employed to estimate private benefits of control. Barclay and Holderness $(1989,1992)$ argue that private benefits of control are reflected in the block premium calculated relative to the post-transaction price. Nicodano and Sembenelli (2000) argue that this methodology is inappropriate, since it neglects ownership structure characteristics in the analysis of control rents. Instead, following Zwiebel's (1995) suggestion, they posit that the fraction of control rights being transferred in a block trade should be measured by changes in strategic importance of shareholders (proxied by changes of Shapley values). Yet another approach is pioneered by Rydqvist (1987) and Zingales (1994), who analyze samples of companies with dual-class stocks. Price comparisons of shares carrying different control rights allows then to make inferences about the value of private benefits of control. The recent study by Nenova (2003) employs this methodology to illustrate the differences in the benefits of control across 18 countries.

\section{Research hypotheses}

\subsection{Valuation hypotheses}

Much of the prior literature suggests that block transactions should be on average value-creating to the shareholders of the focal firm (e.g., Holderness and Sheehan, 1988; Barclay and Holderness, 1989; Sudarsanam, 1996). Investors can expect that a block deal is a prelude to 
an attempted takeover as the acquirer builds a toehold (Shleifer and Vishny, 1986). Positive abnormal performance at the announcement of block transaction may also be due to the expected improvement in corporate governance that would result from an increased intensity of monitoring (cf. Admati et al., 1994; Maug, 1998; Kahn and Winton, 1998). In both cases, the positive effect of the block transaction should be more pronounced in situations, where the block acquirer is an investor committed to monitor and, possibly, restructure the target company (Bethel et al., 1998). ${ }^{5}$ Such a restructuring is only implemented by an investor who plans a longer-term engagement in a company.

The value of monitoring by the incumbent shareholders is already incorporated in the stock price. A new large investor is likely to contribute new corporate ideas to the target firm (Nesbitt, 1994). Moreover, he can have monitoring skills different from those of the incumbents. Consequently, the market reaction to the entry of a new investor provides an estimate for the incremental value creation resulting from the presence of a new block holder.

Hypothesis 1 (Restructuring): The stock price reaction to a block transaction is positive. It is more favorable when the block acquirer is a strategic investor and when he is a new shareholder.

Building up a block by purchasing shares from other large shareholders rather than via a tender offer may indicate that the goal of the acquirer is to extract private benefits at the expense of small investors (Burkart et al., 2000). Dispersed shareholders alone are unlikely to prevent the block holder from extracting excessive private benefits of control, whereas competition among large shareholders could serve this purpose (Bloch and Hege, 2001). A transaction that increases the ownership concentration (e.g. by means of merging some of the blocks) may result in erosion of the relative voting power of dispersed shareholders, even if their nominal stake remains unchanged. The larger the damage to their voting power, and hence the higher the likelihood that a block holder would extract private benefits of control, the less favorably the market perceives a given transaction.

\footnotetext{
${ }^{5}$ For institutional reasons (see Section 5.2), I refer to such a shareholder as a strategic rather than an activist investor.
} 
However, the relationship between the power of dispersed shareholders and the market perception of a block transaction has two aspects: the effect in changes (discussed above) and the effect in levels. While the former one captures a direct damage to the voting power of dispersed shareholders, the latter one measures the scope for future expropriation activities that could potentially be pursued by the controlling (large) shareholders. When a substantial percentage of equity is dispersed (as it often is the case in Poland), even a relatively small block may give control gains due to large absenteeism of shareholders at their annual general meetings, and due to the information disadvantages potentially experienced by small shareholders (Crama et al., 2003). In firms with more dispersed ownership (i.e. the firms where a free float constitutes a larger fraction of the equity outstanding) this problem becomes more severe, since the block holders' incentives to expropriate non-controlling (presumably small) shareholders are stronger (cf. Bennedsen and Wolfenzon, 2000). The agency conflict between small and large shareholders intensifies with the size of the free float large and it is most acute in companies with numerous atomistic shareholders, who can be expropriated.

Hypothesis 2 (Expropriation): The stock market reaction to an announcement of a block transaction is positively related to the change in the relative voting power of dispersed shareholders and negatively related to the size of the free float.

Barclay and Holderness (1989) claim that a block trade can be a signal about the prospects of the firm. Under the assumption that block holders have access to superior information, the market infers that transactions in which a seller is ready to liquidate the position at discount (relative to the market price) signal bad corporate prospects. In contrast, transactions concluded at premium convey good news and trigger positive market reactions.

Hypothesis 3 (Superior Information): Transactions concluded at a premium are followed by a positive abnormal stock performance, while those at a discount are followed by a negative one. 


\subsection{Determinants of block premia}

As noted by Grossman and Hart (1988), Bebchuk (1994), and Zwiebel (1995), the price paid for a significant fraction of voting rights may reflect the possibility of extracting private benefits of control by the transaction parties.

Hypothesis 4 (Existence of Private Benefits of Control): Acquiring a large fraction of control rights requires a premium above the post-trade market price.

The value of control rights may exceed the post-trade market price if the potential extraction of private benefits of control is high. Moreover, the block trade premium may understate the true value of the private benefits because the owner of the equity block incurs the following two costs: (i) liquidation of a large equity position may be costly; (ii) holding a large block of shares limits the possibilities of risk sharing attainable by portfolio diversification (Admati et al., 1994).

The premia calculated relative to the pre-transaction price reflect both shared benefits of control (e.g. expected improvement introduced by a block holder) and private benefits of control (Barclay and Holderness, 1992). After the announcement, the market accounts for the possible value creation due to changes in ownership structure. Therefore the difference between the posttrade share price and the price paid in the block transaction is more informative about private benefits of control (Barclay and Holderness, 1989). The intuition that the possibilities to extract benefits of control are positively related to the degree of voting power is commonly accepted in the literature (e.g. Barclay and Holderness, 1989, 1991; Zingales, 1994, 1995; Nicodano and Sembenelli, 2000). Opinions diverge, however, on the exact functional form of the stipulated relationship. Zwiebel (1995) argues that private benefits of control are divisible and that their allocation depends on ownership structure. ${ }^{6}$ A block entitling to $20 \%$ of votes in a company with widely dispersed ownership is very likely to award its holder with effective control over the company (Crama et al., 2003). A block of $25 \%$ in a company with a majority shareholder usually 
does not give its holder significant influence unless supermajority requirements are imposed. Hence, it is the relative rather than the absolute voting power of a given investor, which determines his ability to enjoy private benefits of control (Crespi and Renneboog, 2003). This implies that premia paid in block transactions should depend not only on the size of the block, but also on the initial and post-trade ownership structure characteristics. By this I do not only refer to the characteristics of the investors selling and acquiring stakes but also to those of all the investors who may be pivotal in a voting game (Crama et al., 2003).

Hypothesis 5 (Relative Power): The premium an investor is ready to pay for the block positively relates to the relative power of a given block holder.

\section{Methodology}

Since the publication of Manne's (1965) paper, corporate control is widely recognized in the financial literature as a major corporate asset. Therefore, it is evident that significant changes in ownership structure, and thus in control, constitute a major corporate event (Barclay and Holderness, 1989; Burkart et al., 2000). If semi-strong market efficiency is imposed, the impact of such an event should immediately be reflected in an appropriate stock price movement. ${ }^{7}$ The analysis of block transactions and their perception enables me also to assess the importance of private benefits of control and draw indirect inferences about agency costs emerging from the interaction of shareholders. Thus, in testing for hypotheses developed in Section 3, event study methodology is applied (as do Barclay and Holderness, 1989, 1991; Keim and Madhavan, 1996; Banerjee et al., 1997).

\footnotetext{
${ }^{6}$ More specifically, it depends on the allocation of voting rights among various shareholders. This distinction is crucial for the companies with dual class stocks (carrying different voting rights).

${ }^{7}$ I assume that the news about block transactions is publicly available information. The plausibility of this assumption might be questioned in the markets characterized by relatively lenient disclosure requirements.
} 
Day 0 signifies the trading day following the block transaction, because all the block trades analyzed occurred and were announced after the closing of the downstairs market. ${ }^{8}$ The estimation period spans 100 trading days. It ends one month before the event, i.e. the window $[-121,-22]$ is used. Such a procedure is appropriate in the analysis of a young market characterized by highly volatile betas. It assures that estimates for the parameters of the benchmark model are not influenced by the event itself (Banerjee et al., 1997). Therefore, it should render reliable and relevant parameter estimates without imposing too rigid data availability requirements (which could result in survivorship bias). The returns are calculated in logarithmic terms, and so conform better than simple ones to the assumptions of the standard statistical techniques (Strong, 1992).

In order to analyze the announcement effect, I assume the event window to be the interval $[0,1]$ instead of analyzing just abnormal performance on day $0 .{ }^{9}$ Such an approach allows for controlling for possible slow reaction of the market, e.g. due to thin trading (MacKinlay, 1997). I employ $\operatorname{CAR}(0,1)$ as the dependent variable in the regression models estimated to test Hypotheses 1-3.

As a benchmark expected return, I employ the market model, which has been shown to outperform alternative specifications (Brown and Warner, 1985). The parameters of the model are estimated by OLS, where the returns on $\mathrm{WIG}^{10}$ are taken as a proxy for market returns. Abnormal return on security $i$ on day $\tau$ is then defined as the prediction error from the market model. Cumulative abnormal returns (CARs) over the interval $\left[\tau_{1}, \tau_{2}\right]$ are defined as the appropriate sums of abnormal returns (ARs), while average abnormal return (AAR) on day $\tau$ and cumulative average abnormal return (CAAR) over the period $\left[\tau_{1}, \tau_{2}\right]$ are computed as crosssectional arithmetic means of the relevant ARs and CARs. The basic procedure employed for

\footnotetext{
${ }^{8}$ This is the rule in Poland: it aims to protect less informed traders. In most cases, day 0 is the press day (i.e. the day on which the information about the transaction is made public).

${ }^{9}$ Sensitivity checks indicate that the conclusions are robust to alternative definitions of the event window.

${ }^{10}$ WIG is a value-weighted index of the Warsaw Stock Exchange. It is the broadest of the Polish stock indices (it includes all the companies listed on the primary market).
} 
testing significance of CARs is a t-test. In the following analyses, I use a Wilcoxon signed rank test and a t-test in order to verify the robustness of the conclusions (MacKinlay, 1997).

Several measures of the level of premia can be found in the literature. The simplest one is the pre-trade premium defined as:

$$
\operatorname{PREMIUM}_{i}=\frac{p_{b i}-p_{m i}}{p_{m i}}
$$

where $p_{b i}$ denotes the price (per share) paid in the $i$-th block transaction, and $p_{m i}$ is the open market share price before the trade. Analogously to Barclay and Holderness (1989), for $p_{m i}$ I take the market price on day (-3). A more appropriate way to estimate private benefits of control requires an analysis of standardized block premia. ${ }^{11}$ They are calculated according to the formula:

$$
S T D_{-} \text {PREMIUM }_{i}=\text { PREMIUM } M_{i} \cdot \alpha_{i}
$$

where $\alpha_{i}$ denotes the fraction of voting rights being transferred in the $i$-th block trade (Barclay and Holderness, 1989). ${ }^{12}$ A post-trade premium and a standardized post-trade premium (POST_PREMIUM and STD_POST_PREMIUM) are two other measures of block premia. They are calculated in a similar way as PREMIUM and STD_PREMIUM but use the post-trade price (i.e. the market price on day 0) as $p_{m i}$. Barclay and Holderness (1991) claim that such premia can be used to construct even more accurate measures of private benefits of control, since they capture the surplus paid above the price which the market perceives to be the fair value of the security after the block trade. I test for significance of post-trade premia and standardized post-

\footnotetext{
${ }^{11}$ Standardized pre-trade premium is employed to test the Superior Information Hypothesis.

${ }^{12}$ In most of the cases it is equivalent to the fraction of voting equity being transferred. However, the sample analyzed contains some companies that issued preferred stock. Such stocks have superior voting rights, i.e. they give their bearer the right to exercise more than one vote per share (in my sample - from two up to five, depending on the company). None of the analyzed block trades involved a transfer of preferred stock. Transfer of such equity is very rare in Poland. Furthermore, only common stocks can be traded on the Warsaw Stock Exchange. Transfer of preferred stocks in listed companies requires the permission of the Securities and Exchanges Commission (KPWiG) and is arranged outside the regulated market.
} 
trade premia in order to verify Hypothesis 4. Moreover, cross-sectional regression models explaining post-trade premia are estimated to test for the Relative Power Hypothesis.

All the regression models are estimated by OLS. I control for possible heteroskedasticity of an unknown form by employing White (1980) heteroskedasticity consistent estimators of the covariance matrix. ${ }^{13}$ In all the regressions I check for potential multicollinearity. The procedure employed involves the analysis of Variance Inflation Ratios (VIFs hereafter, Neter et al., 1996). A model is abandoned due to the collinearity problem if tolerance level of at least one VIF is lower than $10 \%$. All the models reported are free of collinearity problems.

\section{Data}

\subsection{Data collection}

In order to obtain a sample of block trades in Polish listed companies, the archives of Parkiet and Gazeta Wyborcza are examined. ${ }^{14}$ These are the most important newspapers providing information on the Polish stock market. In Poland, not all block transactions (even those involving parties that control more than $5 \%$ of votes) have to be publicly disclosed and it is therefore not possible to obtain the equivalent of the American SEC 13d filing. Moreover, due to the small size of the Polish market, analysts' coverage is much worse than e.g. in the US. Thus, I use press data about block trading.

The sample period spans 44 months: from July 1996 until February 2000. Data for the first half of 1996 and earlier years are not available. The initial sample consists of 146 observations. Some observations had to be excluded from the preliminary sample for the following reasons:

- It is not possible to identify at least one of the parties to the transaction.

\footnotetext{
${ }^{13}$ In models explaining abnormal stock performance, it can be expected that the heteroskedasticity stems from crosssectional differences in variance of the returns. I attempted to model it explicitly and re-estimated Models 1 and 2 by Weighted Least Squares. The results (not reported) are comparable to those obtained from OLS (see Table 4).

${ }^{14}$ Parkiet is an official newspaper of the Warsaw Stock Exchange. Gazeta Wyborcza is the largest Polish daily newspaper.
} 
- Data is unreliable or erroneous. ${ }^{15}$

- The transaction is a response to a tender offer. Following Barclay and Holderness (1991), I exclude such transactions from the sample, since the marginal influence of a particular deal on the ownership structure is then difficult to measure. However, I do not exclude transactions which led to subsequent tender offers. ${ }^{16}$

- The transaction is tied with some other transactions agreed upon or revealed on the same (or very close) date, or more than one deal occurred in the event window. In such cases difficulties in disentangling events occurs.

- The transaction occurs between a company and its subsidiary or among subsidiaries of the same mother-company. In such a case block transaction price may not be very informative (e.g. the transaction may serve as a device of transferring profits within a corporate group).

- One of the transaction parties is a subsidiary of the company whose shares are traded. If such a company acts as a buyer - the deal resembles a share buy-back. If it acts as a seller, the transaction is either some kind of seasoned equity offering, or an anti-takeover mechanism to prevent a hostile takeover. ${ }^{17}$

As a result, 53 block trades remain in the final sample. The variables characterizing ownership structure before and after a transaction are constructed on the basis of the Parkiet ownership-structure database and the same sources, which are used to retrieve transaction details. The ownership-structure database is also used to collect data concerning the number of shares

\footnotetext{
${ }^{15}$ In two cases, the reported fraction of shares held by all block holders exceeded $100 \%$.

${ }^{16}$ Excluding such transactions would diminish sample size substantially. The reason for that is that a shareholder who accumulates at least $10 \%$ of shares of a company within 90 days is legally obliged to bid for the rest of outstanding shares. Exceptions are the situations when State Treasury is the block seller, or when the transaction concerns preferred stock (and thus is carried out outside the regulated market).

${ }^{17}$ Sale of shares to a friendly party can play this role since in Poland subsidiaries cannot exercise their voting rights in the mother company (although they are residual claimants and have dividend rights).
} 
outstanding in the company. Stock prices and stock index values are downloaded from the website of the Bank of Environment Protection brokerage house (Bank Ochrony Srodowiska). The stock prices are dividend-adjusted and split-adjusted. All accounting data come from the Notoria Serwis databases.

\subsection{Variable description}

The sample covers firms from various industries. As illustrated by Table 1, most of the analyzed transactions occur in industrial and financial firms (43.40\% and 37.74\%, respectively), while almost one fifth of the sample firms can be classified as trade and service companies. At the two-digit classification level, banking is the most frequently represented industry with 14 observations (out of 53), followed by electric and machine industry ( 8 cases), food industry ( 7 cases), and construction (6 cases). This diversity assures that the results of the paper are not driven by few industry-specific effects. Consequently, the conclusions drawn are not restricted to any particular industry.

[Tables 1 and 2 about here]

In order to verify the Restructuring Hypothesis, NEW_INVESTOR and STRATEGIC variables are employed as regressors in the models explaining block transaction announcement effects. NEW_INVESTOR is a dummy variable equal to 1 when the block buyer is a new shareholder to the target company. It is the case for about $30 \%$ of the observations (see Table 2).

The STRATEGIC dummy variable equals one when the block acquirer is a strategic investor in the firm (which happens in more than $61 \%$ of the sample cases, see Table 2). In Poland, an investor can be granted such a status by the government (in case of privatizations) or by the target firm's board of directors. In return for certain privileges (e.g., negotiable share price or the option to increase the stake in the target firm via private equity placement), strategic investors are obliged to commit to restructuring the target firm. The scope of commitment and the associated privileges are negotiated between the investor and the board (or the State, in case of privatizations) on case-by-case basis. 
Relative power of block holders and of the dispersed shareholders is measured by oceanic Shapley values (Milnor and Shapley, 1978). The notion of oceanic Shapley value (OSV, hereafter) generalizes the concept of Shapley values used in the analyses of finite games (Shapley and Shubik, 1954). An implicit assumption in computing OSVs is that the dispersed shareholders (sometimes referred to as the ocean) take part in the voting game, though it may not be easy for them to coordinate. ${ }^{18}$ This feature seems quite plausible in the analyzed context.

By definition, the (oceanic) Shapley value of an investor equals the probability that he is pivotal in a randomly formed coalition of investors. Consequently, it not only depends on the size of the stake controlled by a given shareholder, but it also takes into account the dispersion of all the stakes. ${ }^{19}$ This feature advocates the appropriateness of OSVs for testing the Expropriation Hypothesis and the Relative Power Hypothesis. In the regressions explaining block premia, the changes of the buyer's and the seller's OSVs measure the impact of a particular block transaction on parties' strategic strength. Moreover, the pre-trade seller's OSV and the post-trade buyer's OSV are meant to capture the power of respective parties in bargaining over the premium level. Table 2 indicates that a block buyer is usually more powerful a block sellers, already before a transaction. Notably, the changes in buyers' and sellers' relative strength are not mirror images of each other: the average buyer's gain (as measured by $\triangle O S V_{-} B U Y E R$ ) is more than 1.5 times the seller's average loss $\left(\triangle O S V \_S E L L E R\right)$. As a result, a typical block transaction considerably enhances the relative strength of the block acquirer vis-à-vis other shareholders.

\footnotetext{
${ }^{18}$ Provided that absenteeism of small investors at the shareholders' meetings is a rule rather than an exception, the approach suggested by Crespi and Renneboog (2003) is justified. They argue that dispersed shareholders are too small to participate in the voting game (due to e.g. costs of gathering the information, attending shareholders' meetings, etc.) and therefore their role in exerting corporate control is negligible. Consequently, stakes controlled by block holders are re-scaled to sum up to 1 . Then, regular Shapley values are computed for the finite game obtained (Shapley and Shubik, 1954). Applying this approach, my results are qualitatively comparable to those in the regressions reported below. The model fit is usually somewhat weaker.

${ }^{19}$ The stakes are always computed on the basis of voting rights controlled by a given investor. Therefore, in some cases they do not coincide with the fraction of cash flow rights (measured by the fraction of shares held) that characterize those stakes.
} 
Table 1 illustrates also that ownership dispersion in Poland is not very large. In a typical sample company, the free float is quite low and the block holders control more than two thirds of the equity outstanding (or, more precisely, of the voting rights). The measures of voting power for dispersed shareholders (i.e. pre-trade and post-trade oceanic Shapley values corresponding to this group) equal to only 0.269 and 0.242 , respectively. Sample companies differ considerably in this respect, however.

In the models explaining stock market reactions to the announcements of block transactions, I include the PRIVATIZATION control dummy variable. It equals one if the State Treasury is the seller (i.e. for 9 transactions in the sample), and zero otherwise. This variable allows for differences in motives driving privatization decisions and other block sales (Cornelli and Li, 1997). Moreover, in the sensitivity analyses, I employ PROFITABILITY (defined as the industry median-adjusted return on assets), LEVERAGE (proxied by the ratio of the value of debt to the value of the total assets), and the size of the block (measured by $\triangle O S V \_B U Y E R$, $\triangle O S V \_S E L L E R$, or \% OF VOTES) as additional control variables. Shareholder activism may be more beneficial in underperforming firms (Bethel et al., 1998). ${ }^{20}$ Higher indebtedness of the target firm constrains access to free cash flows, making expropriation difficult (Banerjee et al., 1997). Moreover, highly leveraged firms should also benefit more from direct or indirect decreases in expected bankruptcy costs provided by the new stakeholder. Finally, it might be the case that market reaction to larger block transactions is more pronounced than to smaller ones. Therefore, I investigate such a possibility in the sensitivity analyses.

Several control variables are included in the models explaining the level of block premia as well. Nicodano and Sembenelii (2000) indicate that idiosyncratic firm characteristics can influence the value of control rights in a company. Unfortunately, the small size of the sample does not allow me to control for industry-specific effects. I do include, however, variables capturing company profitability, risk, and size. Dyck and Zingales (2004) argue that a troubled

\footnotetext{
${ }^{20}$ Table 2 documents that the sample includes both firms that underperformed and overperformed their industry peer group.
} 
company may inflict a loss in reputation to the controlling party and, in extreme cases, even some legal liabilities. Hence, the value of control may be lower in underperforming firms. I include the PROFITABILITY variable to control for such a possibility. Company risk is proxied by the standard deviation of percentage daily returns on a company's stock within the estimation period. Inclusion of the RISK variable is motivated by Demsetz and Lehn (1985) who argue that monitoring by a large shareholder increases in value, and hence concentrated ownership will be more likely, as the company's risk increases.

Barclay and Holderness (1989) suggest that block holders in larger firms enjoy greater pecuniary and non-pecuniary benefits. However, the cost of holding a block is higher for large companies (Franks et al., 2001). The reasons for that may be the costs of financing the block or an excessive imperfectly diversifiable risk (Nenova, 2003). If the market is not deep enough (in the sense of Kyle, 1985), it might be difficult for a block holder to liquidate a very big position. Finally, large companies are usually subject to more extensive tracking by analysts and monitors, which makes the extraction of private benefits of control more difficult. The FIRM_SIZE variable (defined as the natural logarithm of market capitalization expressed in millions PLN) is meant to control for those effects. As illustrated by Table 2, sample firms differ considerably as far as their size is concerned: the largest sample firm is approximately 960 larger than the smallest one.

In a sensitivity analysis, I use $L E V E R A G E$ as a control variable in the models explaining the block premia. High levels of debt might both increase and reduce control rents (Nicodano and Sembenelli, 2000). Increasing the leverage has a twofold effect. On the one hand, it can increase the size of the company, and thus help to overcome the owners' wealth constraints (Stulz, 1988). On the other hand, it can constrain managerial discretion by restrictive covenants, and by the obligation to pay out future cash flows (Harris and Raviv, 1988), which reduces the possibility of extracting perquisites of control. 
Block holders' characteristics might affect the investors' ability to extract private benefits of control. ${ }^{21}$ In order to control for the possible heterogeneity of block acquirers, I employ the STRATEGIC dummy in sensitivity analyses. There is no reason to assume that all the sellers in block transactions are homogeneous either. They can also pursue various goals. For instance, when the State Treasury is selling its stake in a formerly state-owned company it possibly takes into account other factors than obtaining the maximal possible price for the block. It may follow the criterion of maximizing incumbent stakeholders' interests (which could mean, e.g. sustaining employment) rather than obtaining the highest price (Cornelli and Li, 1997). Therefore I include the PRIVATIZATION dummy in the sensitivity tests as well.

\section{Valuation effects of block transactions}

Table 3 supports the claim that a block transaction is a major corporate event that leads to significantly positive abnormal stock performance around the announcement date. Therefore, the event study results support the Restructuring Hypothesis postulating that expected improvement of corporate governance is induced by a transfer of control. No support for the Superior Information Hypothesis is found: the block transactions concluded at a premium are not perceived better than those concluded at a discount (in fact, Table 3 documents the reverse).

[Table 3 about here]

Table 4 reports the regression models explaining the valuation effects of block transactions. The stock market perceives a block transaction more favorably if the buyer is a strategic investor in the target company. For such transactions $\operatorname{CAR}(0 ; 1)$ exceeds that for other deals by almost 2.5 percentage points. Entries by new block holders are also welcomed by the

\footnotetext{
${ }^{21}$ Shleifer and Vishny (1997) give a Russian example of such differences. They point out that a Western investor can control a Russian company with 75 percent ownership, whereas a Russian investor can do so with only 25 percent stake. Although in other markets, legal protection of all investors is usually (more) equal, the discrepancies can emerge due to differences in monitoring abilities of different shareholders. Moreover, some of the private benefits of control (e.g. synergies) can be enjoyed only by a particular group of investors.
} 
stock market. Abnormal returns for such deals are approximately 2.2 percentage points higher than for other block transactions. If the block acquirer appears to be capable to implement value increasing measures in target firms and to be committed to do so, investors perceive the transaction significantly more favorably. This result supports firmly the Restructuring Hypothesis.

[Table 4 about here]

Investors expect that block acquirers' activism benefits the firm value. Still, the shareholders seem to worry that when the acquirer's control power is unlikely to be challenged, the expropriation threat is more credible. In such cases, accumulating even a small block may provide its holder with effective control. The stock market reaction to a block transaction announcement (i.e., $\operatorname{CAR}(0,1))$ and the size of the free float are negatively related. In the firms where the free float constitutes a larger fraction of the equity outstanding (and therefore the scope for expropriation is bigger), block transfers are perceived less favorably. This effect is economically and statistically significant: for instance, an increase of the OSV_OCEAN (AFTER) variable by one standard deviation $(0.196)$ on average lowers the abnormal return on the announcement of a block transaction by about 1.6 percentage points. This effect in levels, seems to dominate the effect in changes: the coefficient corresponding to the $\triangle O S V \_O C E A N$ is only marginally significant and a one-standard deviation increase in the value of the $\triangle O S V_{-} O C E A N$ decreases $\operatorname{CAR}(0,1)$ by less than 1.0 percentage point. ${ }^{22}$ Therefore, I argue that Models 1 and 2 provide some support for the Expropriation Hypothesis. The apparent concern of the Polish market about possible expropriation of small investors is in line with findings of La Porta et al. (1998). They document inferior minority shareholders' protection in the non-Anglo-American corporate governance systems.

\footnotetext{
${ }^{22}$ Quite surprisingly, the coefficient estimate is negative. It suggests that dispersed shareholders seem to care about potential future expropriation (the threat of which is proxied by OSV_OCEAN (AFTER)), while they are not worried by the deterioration of their voting power directly resulting from a particular block transaction.
} 
The Superior Information Hypothesis postulates that the level of the block premia signals the prospects of the firm. However, Model 2 rejects the claim that the market reacts to such a signal: the relationship between the block trade announcement effect and the level of the premia is insignificant. ${ }^{23}$ Hence, the Superior Information Hypothesis is rejected.

The signs corresponding to the PRIVATIZATION dummy are negative. Privatizations are not favorably received by the market (relative to other block transactions). This seems counterintuitive for two reasons. In (partly) state owned companies, management can be subject to political pressures. Additionally, the State's objectives may be different from profit maximization. For instance, the State could stimulate firms to maintain employment at too high levels (Cornelli and Li, 1997). Consequently, privatizations are expected to result in efficiency gains (Aghion and Blanchard, 1998). If a transfer of control from a public to a private owner is to improve company performance, it should be perceived more favorably (or at least not less favorably) than a block transaction agreed on by private investors. This claim seems doubtful in the light of my results. Possibly, additional covenants included in privatization deals (e.g. conditions sustaining the level of employment, or imposing some investment requirements) are suboptimal from the investors' point of view, making such block acquisitions less attractive. Furthermore, shareholder activism by the State may bring about benefits for the dispersed shareholders. ${ }^{24}$ For instance, the presence of the State in the ownership structure may limit opportunities for other block holders to inefficiently extract private benefits of control.

\section{Determinants of block premia}

The levels of block premia can be used to estimate the value of private benefits of control. Hypothesis 4 postulates that substantial blocks of shares provide opportunities to extract private benefits of control. That is why the acquisition of a block occurs at a premium over the market

\footnotetext{
${ }^{23}$ This result is upheld when a standardized premium is used instead of a simple one.

${ }^{24}$ Under sufficiently weak corporate governance, partial state ownership may be superior to some other types of ownership to stimulate corporate restructuring (Djankov and Murrell, 2002).
} 
price. The data support this hypothesis (see Table 2). Both simple and standardized post-trade premia significantly exceed zero. Relevant t-statistics equal 2.766 and 2.633, respectively, which corresponds to a significance level of approximately $1 \%$. The distribution of premia is illustrated by Figures 1 and $2 .^{25}$

[Figures 1 and 2 about here]

The relatively low level of observed block premia in the Polish market is striking. The average of $0.98 \%$ (for standardized premia) falls in the lower end of the estimate ranges reported by Nenova (2003) or Dyck and Zingales (2004) for various countries. ${ }^{26}$ Moreover, every third transaction in the sample analyzed here involves a discount rather than a premium. The claim that private benefits of control in Poland are comparably low to those in the most developed market economies characterized by good investor protection seems implausible. An alternative explanation may be the presence of liquidity costs faced by block holders in Poland. Some evidence for this argument follows also from the regressions below.

The standardized post-trade premium has an intuitive interpretation, i.e. the value of private benefits as a percentage of the total value of the firm's equity (Barclay and Holderness, 1989). However, in the regression models, I employ the simple post-trade premium as a dependent variable, because the models explaining the standardized premium could suffer from endogeneity problems. ${ }^{27}$ The standardization involves scaling the simple premium by the size of

\footnotetext{
${ }^{25}$ When I limit the analysis to companies following the one-share-one-vote rule, the results for this sub-sample of 39 observations (not reported) are very similar to the ones obtained for the whole sample. Hence, I argue that the presence of companies issuing preferred stock in the sample does not affect the conclusions.

${ }^{26}$ The former paper estimates private benefits of control in Poland to constitute about $11 \%$ of the market value of equity. This result is based on just four block transactions.

${ }^{27}$ I would like to thank an anonymous referee for pointing out this problem.
} 
the block, while some of the regressors (i.e. OSVs and their changes) are actually functions of the size as well. The estimation results are summarized in Table $5 .^{28}$

[Table 5 about here]

In line with the Relative Power Hypothesis, larger incremental changes of the strategic importance of block transaction parties are related to larger premia. In Models 3 and 4, the coefficients corresponding to the changes of OSV for the seller and for the buyer have the expected signs and the former one is marginally significant. ${ }^{29}$ Model 5 tends to indicate that larger sellers with strong voting power (as measured by the respective OSV) are able to obtain higher premia for the blocks sold. Again, the corresponding coefficient is marginally significant. According to Model 6, the larger the post-trade relative power of the buyer, the higher is the block premium paid. The coefficient corresponding to the post-trade OSV of the buyer is significantly positive. The Relative Power Hypothesis is therefore supported. The relative power of block holders determines the level of block premia and the ownership structure seem to affect the opportunities of extracting private benefits of control.

RISK emerges as another variable that has a significant impact on private benefits of control. Apparently, control is more valuable in riskier firms. This result is consistent with option-like character of equity. The estimate corresponding to the FIRM_SIZE variable persists to be negative and highly significant across all four specifications. This result seems to suggest that in Poland, the liquidity costs in the market for blocks may be of some importance. The costs associated with holding a large block (in value terms) appear large enough to outweigh the

\footnotetext{
${ }^{28}$ Barclay and Holderness (1989) argue that the standardized post-trade premia have better statistical properties than the simple post-trade premia. Therefore, despite the concerns raised above, I estimated the models with the standardized post-trade premium as a dependent variable. The results (not reported) are virtually identical to those presented in Table 5.

${ }^{29}$ The change of the seller's OSV is a non-positive number. Hence, the corresponding coefficient is expected to be negative.
} 
positive impact of a company's size on the value of private benefits of control hypothesized by other studies.

My results seem to confirm the positive relationship between firm performance and the value of control postulated by Dyck and Zingales (2004). The estimated effect of the PROFITABILITY variable is positive (although insignificant) across Models 3-6. It appears that the possibilities to extract private benefits of control in well-performing companies are higher than in those that do worse.

\section{Additional analyses and robustness tests}

\subsection{Block transfers and the anticipation of a takeover}

Arguably, a positive reaction to a block transfer and the support for the Restructuring Hypothesis may stem from the anticipation of takeover rather than from the expected restructuring and the increased monitoring by the block acquirer. ${ }^{30}$ Although in about $30 \%$ of the cases analyzed here, a tender offer was made within a year from a block transaction (in 6 cases, a sample company was merged or delisted within this period), I argue that this takeover-threat argument cannot fully explain my results. I document that - even in the absence of a credible takeover threat - the shareholders can benefit from a substantial change in the firm ownership structure.

First, if the favorable reaction to block acquisitions by strategic investors and by investors new to the company was due to the anticipation of a takeover, those variables should have predictive power in explaining the likelihood of tender offers following such a block acquisition. It is not the case, however. I estimated logit models (not reported) where the dependent binary variable equals 1 for firms where tender offer was announced within a year from the analyzed block transactions and 0 otherwise. As the regressors, I employed the variables used in Section 6 to explain the announcement effects. Those models fare quite poorly in explaining the likelihood of a tender offer - in virtually all cases, the model coefficients are not jointly significant at conventional confidence levels. In particular, neither the NEW_INVESTOR nor the STRATEGIC

\footnotetext{
${ }^{30}$ I would like to thank an anonymous referee for raising this issue.
} 
variable reaches a generous $10 \%$ significance level in any of the specifications tried. ${ }^{31}$ Consequently, I argue that those variables are unlikely to capture the effects of an anticipated takeover.

Second, I carried out an event study that analyses operating performance of the sample firms over a period of one year after the block transfer occurred. I employ the return on assets as a measure of the operating performance. I follow the approach proposed by Barber and Lyon (1996) and compare the performance of the sample firms with the performance of a matching portfolio. I use industry and performance matching to construct the industry comparison group. Such a matching procedure renders reliable benchmarks even if sample firms performed unusually well or poorly in the pre-event period (Barber and Lyon, 1996). The firms constituting the industry comparison group meet two criteria. First, they public firms belonging to the same industry (defined at the two-digit level) as the focal firm. Second, their operating performance (ROA) at the end of the last quarter before the block transaction lies within the range of the ROA of the focal firm \pm 0.75 within-industry standard deviation of ROA. ${ }^{32}$

Barber and Lyon (1996) show that benchmarks that incorporate past performance of the focal firm yield well-specified and powerful test statistics. Moreover, they illustrate that change models dominate level models in detecting abnormal operating performance. Following these arguments, I define expected performance as the pre-event firm performance adjusted by the change in the median performance of the industry comparison group (as defined above). Abnormal performance is a difference between the focal firm's ROA at the end of the fourth full

\footnotetext{
${ }^{31}$ In fact, the corresponding estimates are usually negative, which is inconsistent with the takeover anticipation argument discussed above.

${ }^{32}$ Due to the relatively small number of public firms, narrower bands used by Barber and Lyon (1996) render the industry comparison group to be empty. The approach proposed here assures a reasonably numerous groups (average and median portfolios consist of 12 firms, while $85 \%$ of those portfolios comprise at least 5 firms). Still, in one case, such a procedure renders the industry comparison group to be empty. For this observation, I adjust the matching procedure and define the industry comparison group as the two industry peers whose performance is closest to that of the focal firm (which effectively means imposing a band of \pm 1.75 within-industry standard deviation of ROA instead of a standard one. The results of the event study are not driven by this observation and are robust to its exclusion.
} 
quarter after the block transaction and the benchmark. I use a Wilcoxon signed rank test and a t-test in order to verify statistical significance of this abnormal performance. Significance levels discussed below correspond to one-tailed tests.

The results document some improvement of the operating performance (ROA) in the sample firms over a period of one year after the block transfer. On average, the focal firms outperformed the benchmark by $1.104 \%$, which is marginally significant ( $\mathrm{p}$-value for the t-test equals 0.077$)$. The median abnormal ROA is also positive $(0.727 \%)$, while Wilcoxon test indicates that abnormal performance of the sample firms significantly exceeds zero ( $p$-value equals 0.030). The numbers, although not very large, suggest that even the firms that were not taken over recorded some improvement in their operating performance in the year following the block transaction. ${ }^{33}$ Therefore, I argue that not only a completed takeover, but also an acquisition of a substantial block may benefit company shareholders.

Third, the anecdotal evidence (based on the extracts from financial press) suggests that some imprecise clauses in the Polish takeover law in the analyzed period resulted in an insufficient protection of the minority shareholders' interests. In particular, the requirement that “...the minimum price in a tender offer should only be based on a 6-month average price from a period preceding the offer and the right to accumulate the shares with the help of the [acquirer's] subsidiaries allowed for a legal violation of dispersed shareholders' interests. For instance, (...) it was possible to acquire 26\% of shares of Polifarb Dębica for PLN 72 per share in block transactions, and one week later offer PLN 57 per share in a tender". 34 Consequently, in the analyzed period a tender mechanism could be used as a way of squeezing out minority shareholders. Therefore, the effect the anticipation of a tender offer (and a subsequent takeover) may have on a block transaction announcement is not unambiguous. This argument further undermines the takeover explanation for the results of Section 6 and exemplifies a particular kind of expropriation threat that may be experienced by minority shareholders.

\footnotetext{
${ }^{33}$ Obviously, the results of this event study are based on a non-takeover subsample only.

${ }^{34}$ It is a translation of a quote from a press article (Czy będą wzywać? Parkiet, December 7, 2000).
} 


\subsection{Determinants of valuation effects - other robustness checks}

As a sensitivity check I examined the effects of the inclusion of $L E V E R A G E$ and of PROFITABILITY as additional control variables in Models 1-2 (Table 4). Neither of the two proves significant as a determinant of the transaction announcement effects, while none of the conjectures of the models summarized in Table 4 are seriously challenged. Also, the size of the block transferred does not influence the level of $\operatorname{CAR}(0,1)$. The effect is insignificant, irrespectively of the proxy used to measure the block size ( $\triangle O S V \_B U Y E R, \triangle O S V \_S E L L E R$, or \% OF VOTES), while the conclusions of Models 1 and 2 are upheld. Importantly, when the FREE_FLOAT variable is used instead of the OSV_OCAEAN (AFTER) one, all the results hold as well.

I also checked whether the results summarized in Table 4 are not driven by a few influential observations. I winsorized the dependent variable (i.e. $\operatorname{CAR}(0,1))$ as well as both the continuous regressors from Models 1 and 2 (i.e. the FREE_FLOAT and PREMIUM variables). In each case, the winsorization procedure involved replacing the two highest and the two lowest values of a particular variable by the third largest and the third lowest values, respectively. Then, I re-estimated Models 1 and 2 using those transformed variables (rather than the actual ones). The significance levels were only slightly affected, while none of the earlier conclusions were challenged, which warrants the robustness of earlier conclusions.

\subsection{Determinants of block premia - robustness checks}

I also performed some additional sensitivity tests for the models explaining the level of block premia that are reported in Table 5. When LEVERAGE is added as a regressor, the corresponding coefficient is negative (and statistically significant in some specifications), while the significance of some other estimates is affected (possibly due to a substantial decrease of the sample size). Still, the main qualitative conclusions of Models 3-6 remain upheld. I also attempted to control for the identities of the transaction parties, and added the PRIVATIZATION or STRATEGIC dummies to the model specifications discussed above. Block premia paid in privatizations are usually slightly higher, but neither of the two variables considered are 
consistently significant across model specifications. None of the major conclusions purporting to the other variables is materially different.

I also examined whether the results of Table 5 are not driven by outliers. Again, I winsorized the dependent variable (i.e. POST_PREMIUM) as well as all the regressors used in Models 3-6, according to the winsorization procedure discussed in Section 8.2. I re-estimated Models 3-6 with those winsorized variables. Only the significance of the $\triangle O S V$ SELLER variable (in Model 3) decreased materially (the estimate remained negative, however), while the other results remained virtually intact. Thus, I conclude that despite a relatively small sample size, the presence of outliers does not pose a serious problem to the analyses carried out in the paper.

\section{Discussion and concluding remarks}

The current paper presents an empirical analysis of the Polish equity block market. Most of the previous studies examining block trades investigate the American stock market and the well-developed European markets. Hardly any empirical work has been performed to study these issues for the emerging markets of Central Europe. One of the main reasons is that these markets, including the Polish one, are young, which makes it impossible to track the companies in the longer period after block transactions.

The results show that the transfer of control rights that takes place in block trades in Poland constitutes a major corporate event, typically associated with positive abnormal stock performance. In line with the Restructuring Hypothesis, shareholders expect to benefit from intensified monitoring and from corporate restructuring resulting from block acquisitions. Block acquisitions by strategic investors and by shareholders who are new to target companies are perceived significantly more favorably by the market than other block transactions. A more direct evidence of beneficial restructuring is also provided: companies that experience a block transaction enjoy a statistically significant improvement of operating performance following such a change in the ownership structure.

Dispersed shareholders appear to be wary of the expropriation that could follow the extraction of private benefits of control by dominating block holders. Block transactions in firms 
with a larger free float (i.e. the companies where the scope for expropriation is bigger) are perceived less favorably, which supports the Expropriation Hypothesis. Hence, I argue that the costs of excessive ownership concentration may partly offset the benefits resulting from block holders' activism. This result brings about important policy implications, calling for improvement of corporate governance standards.

Although private benefits of control in Poland are likely to be large, the observed block premia turn out to be lower than those documented for most of the other countries. Apparently, the costs of holding equity blocks are substantial, possibly due to liquidity considerations. Hence, the value of corporate control in Poland tends to be relatively low, despite numerous deficiencies in corporate governance standards. ${ }^{35}$ Still, the block premia detected in the sample are positive, which implies that controlling block holders of Polish companies can enjoy some private benefits of control.

The findings reject Superior Information Hypothesis: the level of block premia paid does not seem to convey information about a company's prospects. In line with the Relative Power Hypothesis, the level of block premia depends not only on the size of the block transferred, but also on the dispersion of voting rights. Oceanic Shapley values capture well the strategic importance of owners and their possibilities to extract private benefits of control. Incremental changes of the block holders' relative voting power influence the level of block premia. The larger the degree of control the buyer (seller) achieves (gives up), the higher the block premia paid.

\footnotetext{
${ }^{35}$ In the analyzed period, Poland still lacked an appropriate legal framework and a code of practice. A new corporate law was adopted in 2001 .
} 


\section{References}

Admati, R. A., P. Pfleiderer, and J. Zechner, J., 1994, Large shareholder activism, risk sharing, and financial markets equilibrium, Journal of Political Economy 102, 1097-1130.

Aghion, P. and O. J. Blanchard, 1998, On privatization methods in Eastern Europe and their implications, Economics of Transition 6, 87-99.

Atanasov, V., 2001, Valuation of large blocks of shares and the private benefits of control, Unpublished working paper, Pennsylvania State University, http:/www.personal.psu.edu/staff/v/a/vaa3/valueofblocks.pdf.

Banerjee, S., B. Leleux, and T. Vermaelen, 1997, Large shareholders and corporate control: An analysis of stake purchases by French holding companies, European Financial Management 3, 23-43.

Barber, B.M. and J. D. Lyon, 1996, Detecting abnormal operating performance: The empirical power and specification of test statistics, Journal of Financial Economics 41, 359-399.

Barclay, M. J. and C. G. Holderness, 1989, Private benefits from control of public corporations, Journal of Financial Economics 25, 371-395.

Barclay, M. J. and C. G. Holderness, 1991, Negotiated block trades and corporate control, Journal of Finance 46, 861-878.

Barclay, M. J. and C. G. Holderness, 1992, The law and large-block trades, Journal of Law and Economics 35, 265-294.

Bebchuk, L. A., 1994, Efficient and inefficient sales of corporate control, Quarterly Journal of Economics 109, 957-993.

Becht, M. and A. Röell, 1999, Blockholdings in Europe: An international comparison, European Economic Review 43, 1049-1056.

Bennedsen, M. and D. Wolfenzon, 2000, The balance of power in closely held corporations, Journal of Financial Economics 58, 113-139.

Bethel, J. E., J. P. Liebeskind, and T. Opler, 1998, Block share purchases and corporate performance, Journal of Finance 53, 605-634.

Bloch, F. and U. Hege, 2001, Multiple shareholders and control contests, Unpublished working paper, HEC, Paris, http://campus.hec.fr/profs/hege/papers/BlochHegeMultipleShareholders2.pdf.

Bolton, P. and E. L. von Thadden, 1998, Blocks, liquidity, and corporate control, Journal of Finance 53, 1-25.

Brown, S. J. and J. B. Warner, 1985, Using daily stock returns: The case of event studies, Journal of Financial Economics 14, 3-31.

Burkart, M., D. Gromb, and F. Panunzi, 1997, Large shareholders, monitoring, and the value of the firm, Quarterly Journal of Economics 112, 693-728. 
Burkart, M., D. Gromb, and F. Panunzi, 2000, Agency conflicts in public and negotiated transfers of corporate control, Journal of Finance 55, 647-677.

Coffee, J. C., 1991, Liquidity versus control: The institutional investor as corporate monitor, Columbia Law Review 91, 1277-1368.

Cornelli, F. and D. D. Li, 1997, Large shareholders, private benefits of control, and optimal schemes of privatization, Rand Journal of Economics 28, 585-604.

Crama, Y., L. Leruth, L. Renneboog, and J.-P. Urbain, 2003, Corporate control concentration measurement and firm performance', in: J. Batten and T. Fetherston (eds.), Social Responsibility: Corporate Governance issues, (Elsevier Science, Amsterdam) 125-151.

Crespi, R. and L. Renneboog, 2003, Corporate monitoring by shareholder coalitions in the UK, ECGI Discussion Paper 12/2003, ECGI, Brussels, http://papers.ssrn.com/sol3/papers.cfm?abstract_id=379124.

Demsetz, H. and K. Lehn, 1985, The structure of corporate ownership: Causes and consequences, Journal of Political Economy 93, 1155-1177.

Djankov, S. and P. Murrell, 2002, Enterprise restructuring in transition: A quantitative survey, Journal of Economic Literature 40, 739-792.

Dyck, A. and L. Zingales, 2004, Private benefits of control: An international comparison, Journal of Finance 59, 537-600.

Franks, J., C. Mayer, and L. Renneboog, 2001, Who disciplines the management of poorly performing companies?, Journal of Financial Intermediation 10, 209-248.

Gregoric, A. and C. Vespro, 2003, Block trades and shared benefits from control in Slovenia, ECGI Discussion Paper 29/2003, ECGI, Brussels, http://papers.ssrn.com/sol3/papers.cfm?abstract id=444500.

Grossman, S. J. and O. D. Hart, 1980, Takeover bids, the free-rider problem, and the theory of the corporation, Bell Journal of Economics 11, 42-64.

Grossman, S. J. and O. D. Hart, 1988, One share-one vote and the market for corporate control, Journal of Financial Economics 20, 175-202.

Harris, M. and A. Raviv, 1988, Corporate control contests and capital structure, Journal of Financial Economics 20, $55-86$.

Holderness, C. G. and D. P. Sheehan, 1988, The role of majority shareholders in publicly held corporations: An explanatory analysis, Journal of Financial Economics 20, 317-346.

Jensen, M. C. and W. H. Meckling, 1976, Theory of the firm: Managerial behavior, agency costs, and ownership structure, Journal of Financial Economics 3, 305-360.

Johnson S., R. La Porta, F. Lopez-de-Silanes, and A. Shleifer, 2000, Tunelling, American Economic Review 90, $22-27$. 
Kahn, C. and A. Winton, 1998, Ownership structure, speculation, and shareholder intervention, Journal of Finance 53, 99-129.

Keim, D. B. and A. Madhavan, 1996, Large block transactions: Analysis and measurement of price effects, Review of Financial Studies 9, 1-36.

Kyle, A. S., 1985, Continuous auctions and insider trading, Econometrica 53, 1315-1336.

Kyle, A. S. and J.-L. Vila, 1991, Noise trading and takeovers, Rand Journal of Economics 22, 54-71.

La Porta, R., F. Lopez-de-Silanes, A. Shleifer, and R. Vishny, 1998, Law and finance, Journal of Political Economy $106,1113-1155$.

MacKinlay, A. C., 1997, Event studies in economics and finance, Journal of Economic Literature 35, 13-39.

Manne, H. G., 1965, Mergers and the market for corporate control, Journal of Political Economy 73, 110-120.

Maug, E., 1998, Large shareholders as monitors: Is there a trade-off between liquidity and control?, Journal of Finance 53, 65-98.

Milnor, J. W., and L. S. Shapley, 1978, Value of large games II: Oceanic games, Mathematics of Operations Research 3, 290-307.

Nenova, T., 2003, The value of corporate votes and control benefits: A cross-country analysis, Journal of Financial Economics 68, 325-351.

Nesbitt, S. L., 1994, Long-term rewards from shareholder activism: A study of the 'CalPERS effect', Journal of Applied Corporate Finance 6, 75-80.

Neter, J., M. H. Kutner, C. J. Nachtsheim, and W. Wasserman, 1996, Applied linear statistical models (McGraw-Hill, Boston)

Nicodano, G. and A. Sembenelli, 2000, Private benefits, block transaction premia and ownership structure, Working paper, University of Torino, http://papers.ssrn.com/sol3/papers.cfm?abstract id=212248.

Pagano, M. and A. Röell, 1998, The choice of stock ownership structure: Agency costs, monitoring and the decision to go public, Quarterly Journal of Economics 113, 187-225.

Rydqvist, K., 1987, Empirical evidence of the voting premium, Northwestern University Working Paper no. 35.

Shapley, L. S. and M. Shubik, 1954, A method for evaluating the distribution of power in a committee system, American Political Science Review 48, 787-792.

Shleifer, A. and R. W. Vishny, 1986, Large shareholders and corporate control, Journal of Political Economy 94, 461-488.

Shleifer, A. and R. W. Vishny, 1997, A survey of corporate governance, Journal of Finance 52, 737-783.

Strong, N., 1992, Modeling abnormal returns: A review study, Journal of Business Finance and Accounting 19, 533-553. 
Stulz, R., 1988, Managerial control of voting rights: Financing policies and the market for corporate control, Journal of Financial Economics 20, 25-54.

Sudarsanam, S., 1996, Large shareholders, takeovers and target valuation, Journal of Business Finance and Accounting 23, 295-314.

White, H., 1980, A heteroskedasticity-consistent covariance matrix estimator and a direct test for heteroskedasticity, Econometrica 48, 817-838.

Zingales, L., 1994, The value of the voting right: A study of the Milan Stock Exchange experience, Review of Financial Studies 7, 125-148.

Zingales, L., 1995, What determines the value of corporate votes?, Quarterly Journal of Economics 110, 1047-1073.

Zwiebel, J., 1995, Block investment and partial benefits of corporate control, Review of Economic Studies 62, 161-185. 
Table 1. Industry classification for the sample firms.

\begin{tabular}{|c|c|c|}
\hline Classification & No. of observtions & Percentage \\
\hline Industry: & 23 & $43.40 \%$ \\
\hline Chemical & 4 & $7.55 \%$ \\
\hline Timber and paper & 1 & $1.89 \%$ \\
\hline Electric and machine & 8 & $15.09 \%$ \\
\hline Textile & 1 & $1.89 \%$ \\
\hline Construction materials & 2 & $3.77 \%$ \\
\hline Food & 7 & $13.21 \%$ \\
\hline Trade and services: & 10 & $18.87 \%$ \\
\hline Construction & 6 & $11.32 \%$ \\
\hline Wholesale and retail trade & 1 & $1.89 \%$ \\
\hline IT & 2 & $3.77 \%$ \\
\hline Other services & 1 & $1.89 \%$ \\
\hline Financial services: & 20 & $37.74 \%$ \\
\hline Banking & 14 & $26.42 \%$ \\
\hline Insurance & 5 & $9.43 \%$ \\
\hline Financial services & 1 & $1.89 \%$ \\
\hline Total & 53 & $100.00 \%$ \\
\hline
\end{tabular}

Note to Table 1: Industry classification is based on the Polish Classification of Economic Activity (PKD), which is consistent with the NACE Statistical Classification used by the European Union. 
Table 2. Descriptive statistics of the analyzed variables.

\begin{tabular}{|c|c|c|c|c|c|}
\hline Variable & Mean & Median & Std. dev. & Minimum & Maximum \\
\hline$\%$ OF VOTES & 12.350 & 9.830 & 9.588 & 2.250 & 52.100 \\
\hline$\%$ OF CAPITAL & 12.770 & 9.880 & 9.507 & 2.380 & 52.100 \\
\hline PREMIUM & 9.085 & 10.556 & 19.232 & -33.571 & 42.453 \\
\hline STD_PREMIUM & 1.300 & 0.835 & 3.096 & -6.384 & 8.509 \\
\hline POST_PREMIUM & 6.803 & 9.013 & 17.906 & -31.618 & 42.222 \\
\hline STD_POST_PREMIUM & 0.984 & 0.631 & 2.722 & -4.754 & 8.837 \\
\hline STRATEGIC & 0.612 & 1 & 0.492 & 0 & 1 \\
\hline NEW_INVESTOR & 0.302 & 0 & 0.463 & 0 & 1 \\
\hline FREE_FLOAT & 32.582 & 29.580 & 16.530 & 1.660 & 73.250 \\
\hline OSV_OCEAN (BEFORE) & 0.269 & 0.272 & 0.188 & 0.000 & 0.712 \\
\hline OSV_OCEAN (AFTER) & 0.242 & 0.236 & 0.196 & 0.000 & 0.688 \\
\hline OSV_SELLER (BEFORE) & 0.171 & 0.098 & 0.232 & 0.000 & 1.000 \\
\hline OSV_SELLER (AFTER) & 0.055 & 0.000 & 0.196 & 0.000 & 1.000 \\
\hline OSV_BUYER (BEFORE) & 0.225 & 0.100 & 0.289 & 0.000 & 1.000 \\
\hline OSV_BUYER (AFTER) & 0.406 & 0.246 & 0.362 & 0.000 & 1.000 \\
\hline$\triangle O S V_{-} O C E A N$ & -0.001 & -0.027 & 0.087 & -0.410 & 0.119 \\
\hline$\triangle O S V \_S E L L E R$ & -0.117 & -0.087 & 0.159 & -1.000 & 0.000 \\
\hline$\triangle O S V \_B U Y E R$ & 0.181 & 0.108 & 0.226 & 0.000 & 1.000 \\
\hline PRIVATIZATION & 0.170 & 0 & 0.379 & 0 & 1 \\
\hline PROFITABILITY & -0.203 & 0.000 & 4.953 & -10.268 & 20.129 \\
\hline LEVERAGE & 39.466 & 40.794 & 17.331 & 11.195 & 83.687 \\
\hline FIRM_SIZE & 5.238 & 4.656 & 1.760 & 1.993 & 8.859 \\
\hline RISK & 3.123 & 2.993 & 0.765 & 1.588 & 5.081 \\
\hline
\end{tabular}

Note to Table 2: \% OF VOTES and \% OF CAPITAL denote the percentage of voting rights and of cash flow rights transferred in a transaction, respectively. PREMIUM and STD_PREMIUM denote simple and standardized block premia (in \%), respectively. POST_PREMIUM and STD_POST_PREMIUM are simple and standardized post-trade premia (in \%), respectively. STRATEGIC is a dummy variable equal to 1 in cases where the block buyer is a strategic investor in a target company. NEW_INVESTOR is a dummy variable equal to 1 in cases where the block buyer is a new shareholder to the target company. FREE_FLOAT is expressed in percentage terms and denotes the fraction of voting rights not held by block holders. OSV_OCEAN (BEFORE) and OSV_OCEAN (AFTER) denote pre- and posttrade oceanic Shapley values for the dispersed shareholders, respectively. OSV_SELLER (BEFORE) and 
OSV_SELLER (AFTER) denote pre- and post-trade oceanic Shapley values for the seller, respectively. OSV_BUYER (BEFORE) and OSV_BUYER (AFTER) denote pre- and post-trade oceanic Shapley values for the buyer, respectively. $\triangle O S V \_O C E A N, \triangle O S V \_S E L L E R$, and $\triangle O S V \_B U Y E R$ are the changes in the dispersed shareholders', seller's, and buyer's oceanic Shapley values, respectively. The PRIVATIZATION dummy equals one for the transactions where the State Treasury is a block seller. PROFITABILITY is expressed in percentage terms and proxied by (2-digitindustry median-adjusted) return on assets (measured at the end of the quarter preceding the transaction); the variable is defined only for non-insurance companies). LEVERAGE (only for non-financial companies) is expressed in percentage terms and is proxied by the ratio of the value of debt to the value of the total assets (measured at the end of the quarter preceding the transaction). FIRM_SIZE is measured as a natural logarithm of market capitalization (expressed in millions PLN). Market capitalization is computed as the product of the number of the shares outstanding and the share price on the day preceding a block transaction. RISK (expressed in percentage terms) denotes standard deviation of daily stock returns in the estimation period. 
Table 3. Announcement effects of block transactions

\begin{tabular}{c|c|c|c|c|c}
\hline & CAAR(0, 1) & $\begin{array}{c}\text { Median } \\
\text { CAR(0, 1) }\end{array}$ & t-statistics & $\begin{array}{c}\text { Wilcoxon of } \\
\text { statistics }\end{array}$ & observations \\
\hline Full sample & $1.158 \%$ & $1.115 \%$ & $1.899^{*}$ & $2.058^{*}$ & 53 \\
\hline Transactions at premium & $1.123 \%$ & $1.033 \%$ & $1.665^{\dagger}$ & $1.335^{\dagger}$ & 36 \\
Transactions at discount & $1.233 \%$ & $2.079 \%$ & $2.660^{* *}$ & $1.870^{*}$ & 17 \\
\hline
\end{tabular}

Note to Table 3: Cumulative average abnormal returns are computed as prediction errors from the market model. $\dagger,{ }^{*}$, and ${ }^{* *}$ denote significance at 10,5 , and $1 \%$ level, respectively (for one-tailed tests). 
Table 4. Models explaining announcement effects of block transactions.

\begin{tabular}{|c|c|c|}
\hline Variable & Model 1 & Model 2 \\
\hline INTERCEPT & $\begin{array}{l}2.002 \\
(1.31)\end{array}$ & $\begin{array}{l}2.006 \\
(1.31)\end{array}$ \\
\hline STRATEGIC & $\begin{array}{c}2.525 \\
(1.92)^{\dagger}\end{array}$ & $\begin{array}{c}2.506 \\
(1.94)^{\dagger}\end{array}$ \\
\hline NEW_INVESTOR & $\begin{array}{c}2.259 \\
(1.87)^{\dagger}\end{array}$ & $\begin{array}{c}2.249 \\
(1.89)^{\dagger}\end{array}$ \\
\hline OSV_OCEAN (AFTER) & $\begin{array}{c}-8.250 \\
(-2.31)^{*}\end{array}$ & $\begin{array}{c}-8.313 \\
(-2.31)^{*}\end{array}$ \\
\hline$\triangle O S V \_O C E A N$ & $\begin{array}{l}-11.108 \\
(-1.97)^{\dagger}\end{array}$ & $\begin{array}{l}-11.143 \\
(-1.96)^{\dagger}\end{array}$ \\
\hline PREMIUM & & $\begin{array}{l}0.003 \\
(0.12)\end{array}$ \\
\hline PRIVATIZATION & $\begin{array}{c}-7.048 \\
(-3.78)^{* *}\end{array}$ & $\begin{array}{c}-7.069 \\
(-3.69)^{* *}\end{array}$ \\
\hline No. of observations & 49 & 49 \\
\hline $\begin{array}{c}\mathrm{R}^{2} \\
\text { F-statistic }\end{array}$ & $\begin{array}{c}0.363 \\
4.49^{* *}\end{array}$ & $\begin{array}{l}0.363 \\
3.83^{* *}\end{array}$ \\
\hline
\end{tabular}

Note to Table 4: OLS estimates are reported in the table. Heteroskedasticity-consistent t-values are provided in parentheses. ${ }^{\dagger},{ }^{*}$, and ${ }^{* *}$ denote significance at 10,5 , and $1 \%$ level, respectively (for two-tailed tests). The dependent variable in all models is $\operatorname{CAR}(0,1)$. STRATEGIC is a dummy variable equal to 1 in cases where the block buyer is a strategic investor in a target company. NEW_INVESTOR is a dummy variable equal to 1 in cases where the block buyer is a new shareholder to the target company. OSV_OCEAN (AFTER) denotes post-trade oceanic Shapley value for the dispersed shareholders. $\triangle O S V_{-} O C E A N$ is the change in the dispersed shareholders' oceanic Shapley value resulting from a block transaction. PREMIUM denotes simple (pre-trade) block premium. The PRIVATIZATION dummy equals one for the transactions where the State Treasury is a block seller. 
Figure 1. Post-trade block premia.

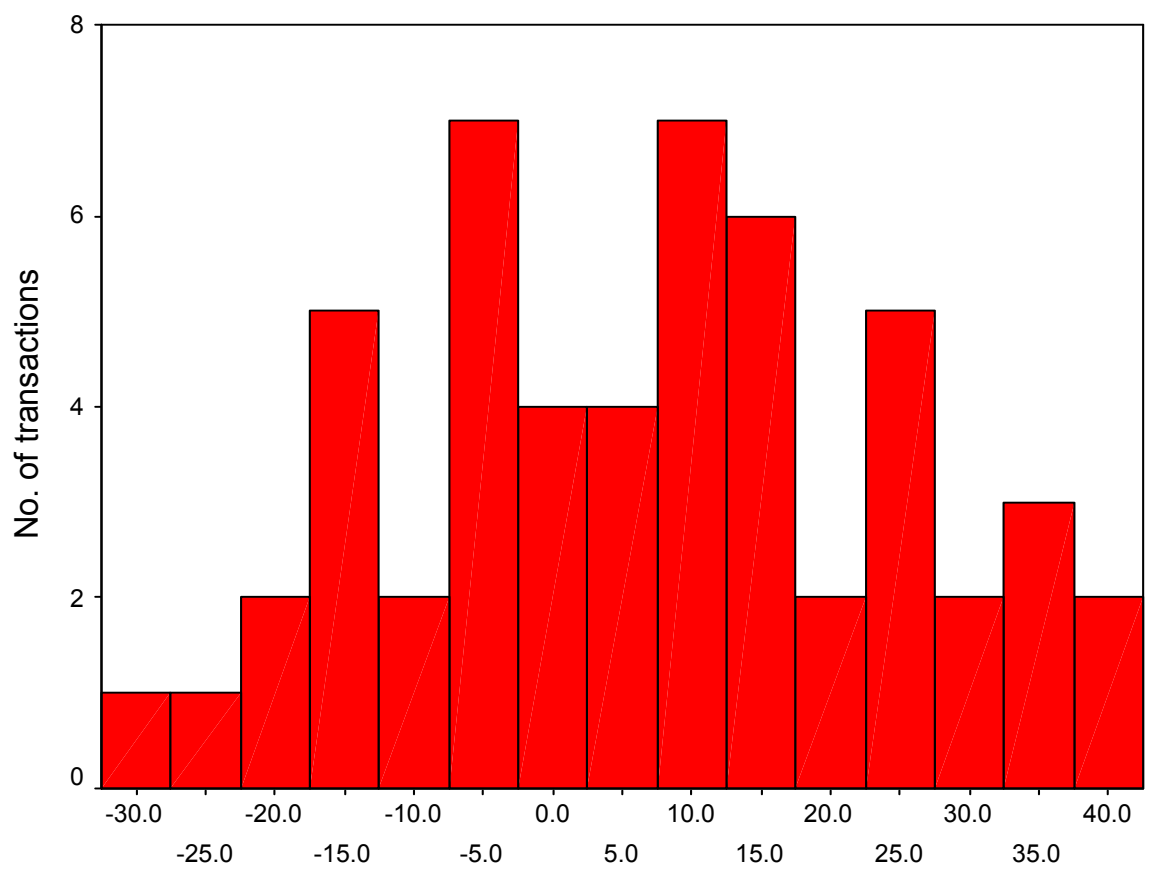

Figure 2. Post-trade standardized block premia.

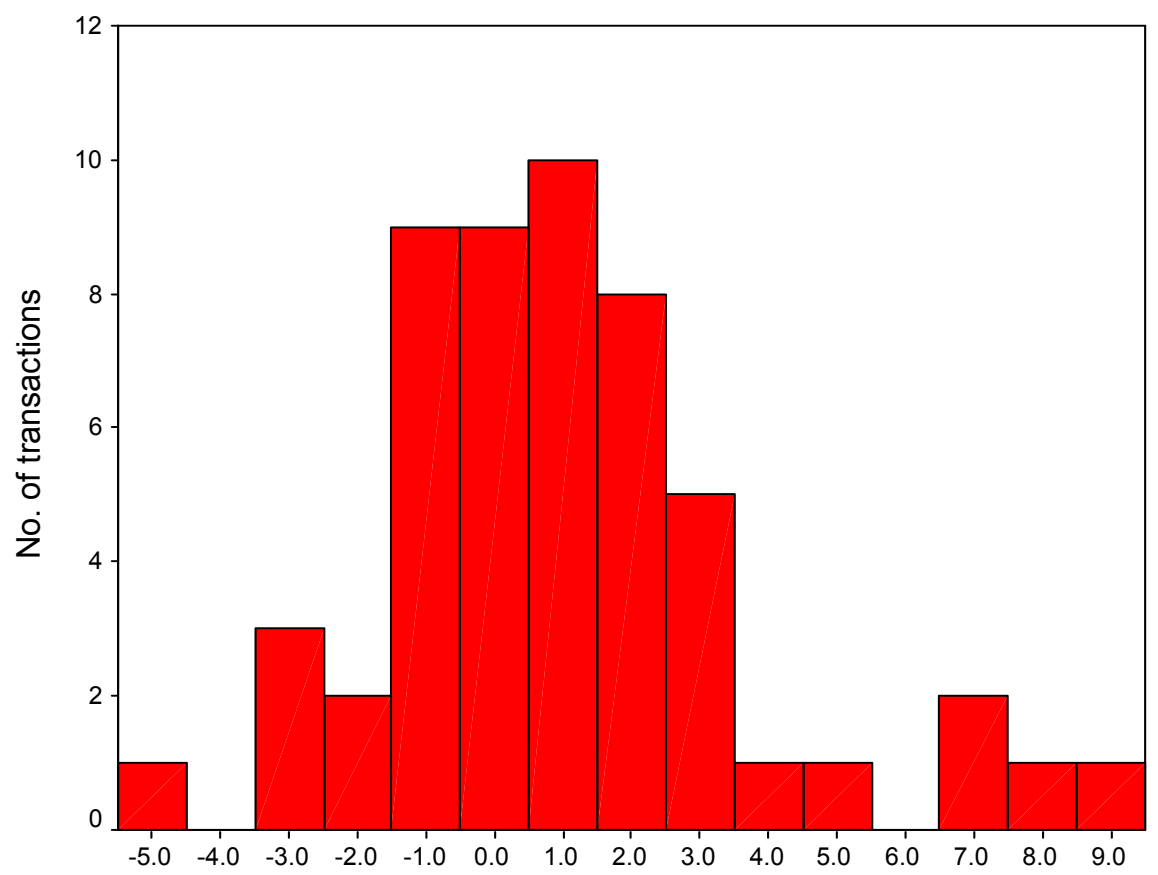


Table 5. Models explaining block premia.

\begin{tabular}{|c|c|c|c|c|}
\hline Variable & Model 3 & Model 4 & Model 5 & Model 6 \\
\hline INTERCEPT & $\begin{array}{l}2.553 \\
(0.23)\end{array}$ & $\begin{array}{l}2.509 \\
(0.22)\end{array}$ & $\begin{array}{l}1.668 \\
(0.15)\end{array}$ & $\begin{array}{l}-0.756 \\
(-0.06)\end{array}$ \\
\hline$\triangle O S V \_S E L L E R$ & $\begin{array}{l}-16.875 \\
(-1.77)^{\dagger}\end{array}$ & & & \\
\hline$\triangle O S V_{-} B U Y E R$ & & $\begin{array}{l}7.091 \\
(0.89)\end{array}$ & & \\
\hline OSV_SELLER (BEFORE) & & & $\begin{array}{l}12.069 \\
(1.83)^{\dagger}\end{array}$ & \\
\hline OSV_BUYER (AFTER) & & & & $\begin{array}{l}12.892 \\
(2.13)^{*}\end{array}$ \\
\hline RISK & $\begin{array}{c}8.171 \\
(2.79)^{* *}\end{array}$ & $\begin{array}{c}8.052 \\
(2.73)^{* *}\end{array}$ & $\begin{array}{c}8.078 \\
(2.85)^{* *}\end{array}$ & $\begin{array}{c}8.129 \\
(2.63)^{*}\end{array}$ \\
\hline FIRM_SIZE & $\begin{array}{c}-4.583 \\
(-3.93)^{* * *}\end{array}$ & $\begin{array}{c}-4.364 \\
(-3.80)^{* * *}\end{array}$ & $\begin{array}{c}-4.387 \\
(-3.83)^{* * *}\end{array}$ & $\begin{array}{c}-4.469 \\
(-3.73)^{* * *}\end{array}$ \\
\hline PROFITABILITY & $\begin{array}{l}0.123 \\
(0.26)\end{array}$ & $\begin{array}{l}0.119 \\
(0.26)\end{array}$ & $\begin{array}{l}0.119 \\
(0.26)\end{array}$ & $\begin{array}{l}0.146 \\
(0.34)\end{array}$ \\
\hline No. of observations & 47 & 47 & 47 & 47 \\
\hline $\begin{array}{c}\mathrm{R}^{2} \\
\text { F-statistic }\end{array}$ & $\begin{array}{c}0.313 \\
7.44^{* * *}\end{array}$ & $\begin{array}{c}0.298 \\
8.21^{* * *}\end{array}$ & $\begin{array}{c}0.318 \\
9.87^{* * *}\end{array}$ & $\begin{array}{c}0.356 \\
11.06^{* * *}\end{array}$ \\
\hline
\end{tabular}

Note to Table 5: OLS estimates are reported in the table. Heteroskedasticity-consistent $t$-values are provided in parentheses. ${ }^{\dagger},{ }^{*},{ }^{* *}$, and ${ }^{* * *}$ denote significance at $10,5,1$, and $0.1 \%$ level, respectively (for two-tailed tests). The dependent variable in all models is post-trade premium (in \%). $\triangle O S V_{-} B U Y E R$ and $\triangle O S V_{-} S E L L E R$ are changes in the buyer's and seller's oceanic Shapley values, respectively. OSV_SELLER (BEFORE) and OSV_BUYER (AFTER) denote oceanic Shapley values for the seller (pre-trade) and for the buyer (post-trade), respectively. RISK denotes the standard deviation of daily stock returns in the estimation period. FIRM_SIZE is measured as a natural logarithm of market capitalization (expressed in millions PLN). PROFITABILITY is proxied by (2-digit-industry median-adjusted) return on assets. 